\title{
Resenha
}

\section{SISTEMA FAXINAL - TERRAS DE PLANTAR, TERRAS DE CRIAR}

\author{
Maycon André Zanin \\ Mestrando em História na Universidade Estadual do Centro-Oeste (UNICENTRO-PR)
}

NERONE, Maria Magdalena. Sistema Faxinal: terras de plantar, terras de criar. Ponta Grossa: Editora UEPG, 2015. 220 p.

O livro Sistema Faxinal: terras de plantar, terras de criar, é o resultado das pesquisas para o desenvolvimento da tese de doutorado de Maria Magdalena Nerone, defendida no Programa de Pós-Graduação em História da Universidade Estadual Paulista, UNESP Campus de Assis. Em seu livro a autora analisa o sistema de uso comum da terra denominado como "faxinal" a partir de um ponto de vista sociocultural, englobando também aspectos da economia, política e do meio ambiente.

No desenvolvimento da pesquisa pode-se destacar a interdisciplinariedade envolvendo diferentes áreas do conhecimento, utilizando entrevistas para recriar determinados aspectos do dia a dia da comunidade. Conceitos como região, memória, espaço coletivo, comunidade, cultura popular, práticas e estratégias, entre outros, estão presentes nas suas discussões, num diálogo fecundo com a Antropologia, Sociologia e outras áreas do conhecimento.

Para a compreensão da ocupação das terras da Península Ibérica, Nerone dialoga com Angel Cabo Alonso, Jorge Dias e Vergílio Taborda, sendo que estes e outros autores analisam o modelo de ocupação das terras portuguesas e espanholas. Este modelo segundo a autora, serviu de exemplo para a ocupação das terras tanto da América portuguesa quando da espanhola, na instalação das reduções pelos padres jesuítas.

Outros autores consagrados também estão presentes na sua pesquisa como, Durval Muniz de Albuquerque Júnior, Philippe Ariès, Bronisław Malinowski, Maurice Halbwachs, Caio Prado Júnior, Michael Pollak e outros tantos pesquisadores que auxiliam nas diferentes 
análises realizadas pela autora sobre o sistema faxinal.

O livro é composto por cinco capítulos, baseados na estrutura empregada na escrita da sua tese. Sendo eles: Origens do sistema faxinal: da Península Ibérica ao Paraná; A posse e o uso da terra no sistema faxinal; Organização: trabalho comunitário e doméstico no faxinal; Sociabilidades: manifestações culturais e religiosas e por fim a Desagregação do sistema faxinal.

Origens do sistema faxinal: da Península Ibérica ao Paraná. Neste capítulo a autora busca, numa perspectiva histórica, a origem do sistema de uso coletivo da terra em outras culturas, demonstrando que a exploração coletiva da terra era um costume comum nos diferentes povos que ocuparam a Península Ibérica e região, e que foram incorporados nas ocupações das Reduções Jesuíticas. Considerando a ocupação realizada pelos padres jesuítas, a autora pode identificar algumas características presentes tanto na Península Ibéria quanto nas reduções, que persistiam também nos faxinais.

Para a autora,

"As primeiras ocupações efetivas em solo paranaense são decorrentes da articulação expansionista e da modalidade diversificada de colonização impostas pelos espanhóis e portugueses, de modo que o surgimento da propriedade de uso coletivo no Paraná decorre da aplicabilidade de um desses modelos". (NERONE, 2015, p. 40).

Para confirmar suas considerações, a autora busca nos arquivos espanhóis informações sobre a ocupação de terras na Europa e a aplicação deste modelo na ocupação das terras da América.

No segundo capítulo, a autora procura caracterizar as partes de terras de uso particular e coletivo do sistema faxinal, descrevendo os principais elementos da organização desse sistema e analisando questões do uso da terra e a posse da mesma. Seu texto mostra como são divididas e ocupadas as terras de criar e plantar pelos moradores. Nerone nos diz, que "no sistema faxinal há um modo específico de seus habitantes organizarem e distribuírem o espaço de sua moradia, que não é junto com a plantação, como os demais colonos do meio rural, mas junto com os animais e da floresta”. (NERONE, 2015, p. 81).

Os costumes e as práticas sociais presentes no imaginário dos faxinalenses também são descritos e analisados pela autora, que apresenta a descrição das habitações e as construções das propriedades.

As construções são sempre próximas às matas e com acesso fácil às construções destinadas a proteção dos animais. O sentimento de pertencer a este lugar está relacionado 


\section{Sistema Faxinal - terras de plantar, terras de criar}

com o vínculo que o faxinalense tem com o espaço habitado e compartilhado por ele e seus vizinhos.

Sobre a organização: trabalho comunitário e doméstico no faxinal, Nerone observou neste momento a articulação dentro do faxinal e a forma de produção dos bens econômicos, tanto individual-familiar quanto coletiva. Analisa quais são os papéis dos atores presentes nas diferentes modalidades de compadrio, e suas práticas formais e informais entre os compadres. Para a autora, "embora os laços de solidariedade fossem nítidos e a hospitalidade uma característica do meio rural, prevaleciam às recomendações pessoais, as quais tinham um poder maior que a de um presidente de província.” (NERONE, 2015, p. 108).

As relações sociais e de poder também são analisadas, nos papéis desempenhados pelo inspetor de quarteirão e do inspetor municipal (autoridades locais), com sua escolha podendo ser influenciada pelo líder político local. Outros agentes que exerciam certa influência na comunidade são o padre, o capelão, os benzedores e as parteiras. Os trabalhos das mulheres e os hábitos alimentares também são analisados neste capítulo. As normas que regem a convivência do grupo familiar, dos vizinhos que dividem o mesmo espaço

Segundo a autora, a ligação com a terra e as atividades agro-pastoris são componentes da identidade do faxinalense, onde as relações de compadrio entre os membros são bastante fortes.

No decorrer do quarto capítulo a autora analisa a sociabilidades: manifestações culturais e religiosas. São descritas as festas religiosas e o folclore presentes nos faxinais. Destacando as principais festividades religiosas dos faxinalenses, apresenta de maneira descritiva as festas de São Sebastião, São João, Nhá Bisília, A bandeira do Divino, A dança de São Gonçalo e o Fandango. As rotinas das festividades são reconstruídas por meio de entrevistas com os organizadores destas festas e fotos destes eventos comunitários, onde tanto na participação coletiva da comunidade quanto na organização e participação nos festejos, fortalecem o sentimento de pertencimento e identidade desta comunidade.

Segundo Nerone,

"No decorrer do tempo, a comunidade rural persiste mais ou menos viva, desde os tempos mais antigos até hoje, não estando dissociada das transformações econômico-políticas, mas com vida e história próprias. Em uma comunidade, os membros revelam tradições, modos de falar, maneiras distintas de ser, sinais e resultados da vida comum que os distinguem dos demais." (NERONE, 2015, p. 139).

Percebe-se na leitura deste capítulo a preocupação da autora em retratar o cotidiano das manifestações culturais presentes nos faxinais, reconstruindo com entrevistas o dia a dia 
das festividades e da religiosidade popular presentes nesta comunidade.

No capítulo sobre a desagregação do sistema faxinal, a autora apresenta uma série de fatores que influenciam na desagregação do sistema faxinal. Destacando a ausência de legislação específica que auxilie os moradores destas localidades nos conflitos em relação a delimitação das propriedades. A migração de agricultores de outras regiões do país para regiões próximas aos faxinais também exercem influência na desarticulação deste sistema, além do desinteresse das novas gerações, que deixam os faxinais em busca de melhores condições de vida na cidade.

Na opinião da autora,

"As comunidades de faxinais, como também grupos negros em outras localidades brasileiras, vivenciam um tempo de transformações, em que se torna difícil manter a antiga ordem social constituída no âmago da história particular de cada um desses grupos. De forma geral, a crise no campo que envolve terras de índio, comunidades negras, faxinais entre outras, esta relacionada também com a falta de um respaldo legal normativo que lhes assegure e reconheça o direito de ser e existir dentro da sua lógica e de sua identidade." (NERONE, 2015, p. 178).

A instalação de cercas individuais para a demarcação das propriedades dentro dos faxinais feitas pelos compradores de "fora" e o êxodo rural têm contribuído para a desarticulação do sistema de faxinal.

Ao termino do livro a autora traz uma séria de sugestões que visam melhorar a qualidade de vida nos faxinais. Dentre elas sugere a implantação de um programa de turismo rural e a criação da Casa da tradição, onde os moradores apresentariam tema da cultura local. No campo educacional, apresenta uma série de possibilidades, que vão desde a criação de grupos de estudos sobre os faxinais até implantação de cursos de extensão para capacitação dos faxinalenses.

Ao término do livro é possível perceber o esforço da autora em entender os problemas e a cultura dos faxinalenses, procurando alternativas para evitar a desagregação deste sistema. Grande parte do conteúdo apresentado neste livro pode vir a auxiliar aos pesquisadores que querem entender a organização dos faxinais, podendo também ser empregados na análise de terras quilombolas ou aldeias indígenas. 